JOURNAL OF SECURITY AND SUSTAINABILITY ISSUES

ISSN 2029-7017 print/ISSN 2029-7025 online

2019 December Volume 9 Number 2

http://doi.org/10.9770/jssi.2019.9.2(14)

Scopus

\title{
TRANSNATIONALISATION AND SEGMENT SECURITY \\ OF THE INTERNATIONAL LABOR MARKET
}

\author{
Svetlana Drobyazko ${ }^{1 *}$, Iryna Alieksieienko ${ }^{2}$, \\ Maryna Kobets ${ }^{3}$, Elena Kiselyova ${ }^{4}$, Mykola Lohvynenko ${ }^{5}$ \\ ${ }^{1}$ European academy of sciences, 111 New Union Street, Coventry, United Kingdom \\ ${ }^{2}$ Dnipropetrovsk State University of Internal Affairs, 26, Gagarina Ave., Dnipro, 49005, Ukraine \\ ${ }^{3}$ State Research Institute of the Ministry of Internal Affairs of Ukraine, 4a Y. Gutsalo Lane, UA-01011 Kyiv, Ukraine \\ ${ }^{4,5}$ Sumy State University, 2, Rymskogo-Korsakova st., 40007 Sumy, Ukraine \\ E-mail: ${ }^{1 *}$ drobyazko.s.i@gmail.com (corresponding author)
}

Received 16 February 2019; accepted 10 October 2019; published 15 December 2019

\begin{abstract}
The scientific paper identifies the leading processes of transnationalisation of the international labor market and the security factors of its existence. The degree of influence of direct foreign investments on the market of national labor resources was determined. The correlation relationship between the foreign investment and the creation of new workplaces in foreign divisions by TNC was studied. The segment security of the international labor market was studied under the influence of the formation of value chains in the environment of TNC.
\end{abstract}

Keywords: segment security; international labor market; outsourcing; employees of foreign affiliates of transnational corporations; employment effect; foreign direct investment; value chain

Reference to this paper should be made as follows: Drobyazko, S., Alieksieienko, I., Kobets, M., Kiselyova, E., Lohvynenko, M. 2019. Transnationalisation and segment security of the international labor market. Journal of Security and Sustainability Issues 9(2): 547-559. http://doi.org/10.9770/jssi.2019.9.2(14)

JEL Classifications: C10, M14

\section{Introduction}

The mobility of work places in the context of globalization is largely determined by the readiness of specific national economies to receive foreign financial or material capital. But even in the conditions of investment hunger, many states are not ready to fully open their national markets to foreign investors, or the multinational companies themselves do not risk implementing the full production cycle in the territory of the receiving countries. This creates a variety of forms of foreign presence in the economy of individual countries and regions of the world, as well as the variability of ways to create work places. The vast majority of transnational corporations (TNCs) entering foreign markets is associated with their desire to reduce the costs of the production process and obtain super-profits, primarily through the use of cheap labor from different segments of the global labor market, affecting its structure and safety. Complex issues of the functioning of the international labor market and the influence of TNCs on international production and labor processes are investigated by such scientists as (Barlett, Ghoshal, 2016; Guest, 2014; Huselid, 2015; Mathis, 2011; Pauly, Reich, 2016; Roberts, 2017; Smethurst, 2016; Truss, et. al., 2016; Torrington, et. al., 2012; Garbowski, M., Drobyazko, S., et. al., 2019; Dobrovolskienė et al., 2017; Nikitina et al., 2018; Tvaronavičienė, 2019; Lialina, 2019; Zeibote, et al. 2019). 
The aim of the scientific paper is to study the strength of the value chains created by TNCs and investing in foreign affiliates in the international labor market segments and determining the safety status of their functioning.

\section{Literature Survey}

The motive for using cheaper labor is increasingly referred to the term "international outsourcing", but not all actions of large companies on the transfer of production capacity (also work places) abroad should be interpreted as follows. In theoretical and methodological terms, the concepts of "international outsourcing" or "offshoring" and "foreign direct investment (FDI)" should be distinguished as processes that are closely related to the mobility of labor resources and the creation of new work places in individual national economies. In our opinion, the following classification of forms and mobility of work places is possible (Fig. 1).

In this particular case, mobility must be understood primarily as the creation of new work places in the countries receiving foreign investment (Kostova, Roth, 2013). In our opinion, two main forms of creating work places through transnationalisation should be distinguished: foreign direct investment and "independent commercial contracts" (international outsourcing), the choice of one of which depends on the goal of creating a business abroad, but always implies more favorable conditions in form of cost savings on labor costs (Gereffi, Fernandez-Stark, 2011a; Drobyazko, S., et. al., 2019; Shuyan, Fabuš, 2019; Shvetsova et al. 2018; Ahmed et al., 2018).

Within the framework of the above forms, it is possible to identify ways to create new jobs, which represent a mechanism for organizing production or providing services abroad. Within the framework of the first form, two main ways can be designated: horizontal and vertical FDI. In the second form - foreign collection, the production of final products or the production of intermediate products. Their choice within the framework of one form or another largely depends on the technological production and qualification of the local labor resources at the disposal of the owner.

As you know, TNC production activity combines a number of interrelated stages, which are organized in the form of a vertical chain that includes the production process itself, as well as activities for developing the product idea, purchasing resources and delivering it to the customer. It is this sequence of actions in the economic literature that is called the value-added chain (VAC), where each link adds a certain value to the originally used resources (Gereffi, Fernandez-Stark, 2011b; Reznik, O., et.al., 2019).

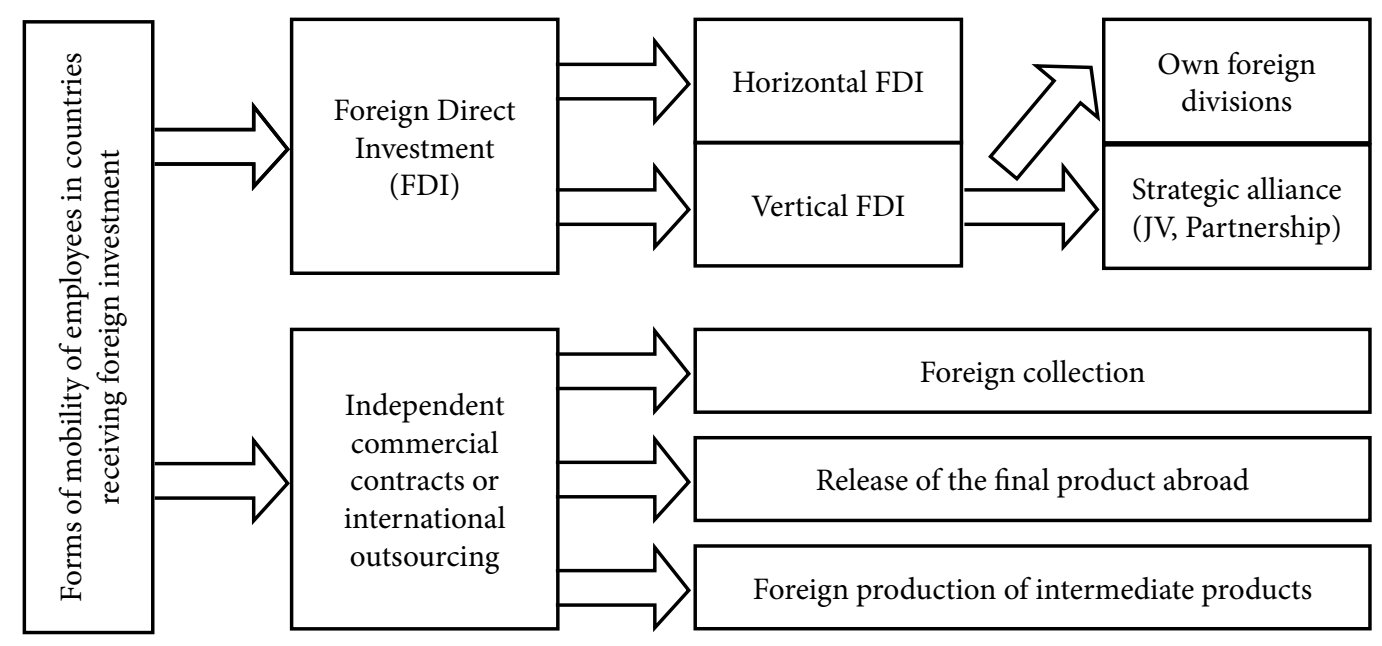

Fig 1. Forms and methods of work places mobility in countries receiving foreign investment 
When it comes to cross-border value chains, the concept of production fragmentation comes to the fore. Global value chains mean that firms place individual links in different geographic locations, often in different countries and regions. They find it profitable to place separate stages of the production process in the territories that can offer the most effective implementation of certain production tasks. Now, value chains are usually built as follows: low-cost production and collection are located in countries with markets (in China and other countries of Southeast Asia) that are developing, and final consumers are in Europe, North America and in Asia (Gereffi, Fernandez-Stark, 2011b).

Thus, international supply chains can be organized both within the same TNC and through contractual agreements with other companies. For example, US statistics still takes into account the number of jobs transferred abroad in two directions: intra-company channels or the conclusion of contracts with third-party organizations.

Both forms of making production abroad satisfy the "placement benefit" factor, since they benefit from better and lower prices of production factors. These forms may differ in the "property benefit" factor, since property is a specific asset; and on the "internationalization benefit" factor, since it would be more profitable for the firm to use the assets on its own than to enter into contractual relations with another independent company (Korauš, et. al., 2019).

\section{Methods}

Taking all of the above into account, we came to the conclusion that the use of one of the forms and methods for attracting investments and creating new jobs is associated with the action of a number of factors. The choice depends on the effectiveness of the national labor market and the security of its organizational functioning, the presence of potential effects from attracting FDI, as well as the absence of certain barriers to attracting a foreign investor. In addition, labor intensity, capital intensity and manufacturability of production are important.

\section{Results}

The question of the influence of TNC on mobility and work places creation in the world, in our opinion, remains debatable. Until now, the studies were fragmentary, based on aggregated data on the number of jobs created by TNCs in conjunction with the effects of employment associated with changes in the structure of foreign trade generated by the activities of TNCs. The positive effect on the global labor market is mainly due to foreign direct investment being imported, although here they must correspond to domestic macroeconomic indicators.

Scientists (Antras, et al., 2012; Dietzinbacher, Romero, 2007; Harter et al., 2012) came to the conclusion that almost half of work places in most countries of the world are related to serving the interests of TNCs. Influencing the international labor market, TNCs create certain models of employment within the country and in the receiving countries, creating turbulent labor flows, putting pressure on the segment separation of these markets and security of operations.

\subsection{Influence of direct investment on segment security of the international labor market}

Global production of TNCs can have direct and indirect effects on employment and the level of security of national labor markets, which should be assessed on the basis of domestic and foreign investments made by TNCs. Employment is also affected by the main subject of investment. UNCTAD experts compiled a table determining the possible effects of employment from the use of various TNC strategies (UNCTAD Annual Report (2018).

Based on UNCTAD data, it can be noted that foreign investments do not so much affect the number of work places, but their quality and movement. Among the positive effects of importing FDI are improvements in the quality of labor and its productivity, as well as the emergence of new organizational methods of work against 
the background of the emergence of new work places in areas with a growing supply of labor (Ciobanu, et. al., 2019). The main negative effect on FDI imports is increased competition for local producers, and, as a result, employment problems for workers employed in their enterprises. The positive effects of FDI exportation are improving the skills of local employees by rationalizing production, manufacturing products with higher added value, and as a result the heyday of advanced industries. Negative effects of FDI exports can be expressed in the loss of jobs due to their movement abroad, increased pressure on wages of local employees (UNCTAD Annual Report (2018).

If we talk about trends in the number of people employed in the structure, over the past 25-30 years their number has only increased. Tab. 1 presents the dynamics of the number of employees of foreign affiliates of TNCs.

Table 1. Dynamics of the number of employees of foreign affiliates of TNCs, thousand people

\begin{tabular}{|c|c|c|c|c|c|c|}
\hline Year & 1980 & 1991 & 2006 & 2010 & 2013 & 2017 \\
\hline Number of employees & 21524 & 24476 & 57799 & 79825 & 96135 & 128775 \\
\hline
\end{tabular}

Source: UNDP. Human Development Report 2018

As for developing countries, the opposite situation arises, when TNCs place the main number of jobs not abroad, but in the countries of their main base. Sectoral structure in principle corresponds to the sectoral structure of TNCs, based in developed countries. As a result, the geography of TNCs is not diverse, the bulk of TNCs are concentrated in the Republic of Korea, Hong Kong, Singapore, China, Mexico and the United States.

The unprecedented growth of FDI in recent decades has caused significant changes in the labor market and their segment security, both in developing and developed countries FDIs bring capital, technology to target countries, industries, affecting the demand for labor and, thus, the composition of labor, employment, labor productivity, wages, and wage differentials. FDI leads to an increase in "skill premium," which is the difference between the wages of skilled and unskilled employees. At the same time, if in developing countries we can argue about the existence of a direct positive effect of FDI on employment in the country as a whole and in foreign affiliates of TNCs, in particular, in developed economies the effect on employment is more complex and mixed. In terms of side effects, we can talk about the positive impact of FDI on the increase in wages and productivity of local firms as a result of direct investment by TNCs in the same industry. FDI expands the production structure of the economy, creating opportunities for production of more complex products or introducing more advanced technologies, thereby increasing the demand for skilled labor. This leads to an increase in the overall demand for labor, an increase in wages for skilled labor, which, in turn, leads to an increase in the qualification level of employees, an increase in average wages and an increase in labor productivity. These effects are especially large in countries where skilled labor is scarce and the technological gap is significant.

For the empirical verification of the above statements, how the FDIs involved in the economy are correlated with the number of jobs created, 23 national economies were selected which proportionally represent the share in the FDIs received and the number of employees in the branches of TNCs (about $12 \%$ of their total). Among the countries studied, 2/3 are represented by developed countries (most of the countries studied are from Europe, the countries of the traditional direction of foreign investment and migration of employees), 1/3 are developing (mainly Asian, in particular countries with dynamic markets), that, in general, is close to the overall structure and recent trends in FDI in the world and the structure of employment of employees in branches of TNCs in the XXI century (Table 2). 
Table 2. Correlation matrix of FDI and work places created by TNCs in foreign divisions

\begin{tabular}{|c|c|c|c|c|}
\hline \multirow{13}{*}{ 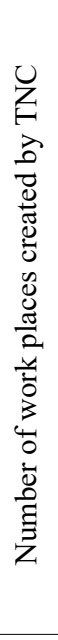 } & \multicolumn{4}{|c|}{ Inflow of foreign investments, million USA dollars } \\
\hline & Austria & China & Germany & Italy \\
\hline & $-0,6$ & 0,98 & 0,46 & 0,7 \\
\hline & Malaysia & Singapore & Taiwan & USA \\
\hline & 0,97 & 0,08 & 0,42 & $-0,24$ \\
\hline & Hungary & Ireland & Switzerland & Japan \\
\hline & $-0,44$ & 0,87 & $-0,48$ & 0,57 \\
\hline & Norway & Sweden & Czech Republic & Finland \\
\hline & 0,64 & 0,15 & 0,08 & 0,47 \\
\hline & France & Luxembourg & Macao, China & Mozambique \\
\hline & 0,89 & $-0,9$ & 0,9 & $-0,82$ \\
\hline & Portugal & Slovenia & Sri Lanka & \\
\hline & 0,93 & 0,62 & 0,48 & \\
\hline
\end{tabular}

Source: UNCTAD Annual Report 2018; calculation authors

Based on the results of the correlation analysis, it can be concluded that there are four groups of countries:

1. group of countries with the highest positive correlation values, which means that there is an unequivocal connection with the growth of work places in TNC enterprises and an increase in FDI inflows, that is, the greater the FDI volume is, the more work places are created by TNCs (such countries are 10: China, Italy, Malaysia, Ireland, Japan, Norway, France, Macau, Portugal, Slovenia);

2. group of countries with low positive correlation values (up to 0.5), which does not allow us to speak about the existence of a unique connection between the growth in the volume of imported FDI and the increase in the number of work places (this includes 7 countries: Germany, Singapore, Taiwan, Sweden, Czech Republic, Finland, Sri Lanka);

3. group of countries with low negative correlation values (up to 0.5), which does not allow to speak about the existence of a close connection between the volume of imported FDI and the growth in the number of work places, nor about the growth in the number of work places under the influence of FDI (this includes 3 countries: the USA, Switzerland, Hungary).

4. group of countries with high negative correlation values, which means the presence of connection between the ratio of the volume of imported FDI and the dynamics of work places growth. It can be argued that the increase in the volume of imported FDI either does not lead to an increase in the number of work places, or generally causes their reduction (this group includes 3 countries: Austria, Luxembourg, Mozambique);

It is obvious that in most of the countries studied there is a positive connection between the volume of imported FDI and the number of work places created, which allows us to conclude that FDI has a positive effect on employment processes within national labor markets.

In order to verify our assumption that the number of people employed in TNCs depends on the amount of initial investment (Greenfield Investment), the cost of mergers and acquisitions (M\&A), and also introducing an additional factor to the average wage in the country of origin of investments, we built a model of correlation and regression analysis. The model output data included indicators for 20 countries in Europe and Asia for which comparative figures were available for all three of the above factors for 2017. The choice of this model is due to the fact that it is quite convenient from the point of view of the possibility of an objective assessment and determining the impact on the dependent variable (for our model, the number of employees in the branches of TNCs) from a number of quantitative factors that in our opinion have a significant impact on the subject of analysis (Pickard, 2016).

The authors built a regression model in the form of: 


$$
Y=f(x)+u
$$

In the case of linear regression, the form of the relationship between the dependent variable $(\mathrm{Y})$ and the independent variables $\left(x_{1} \ldots x_{m}\right)$ will be:

$$
y=a_{0}+a_{1} x_{1}+a_{2} x_{2}+\ldots+a_{m} x_{m}
$$

The values of the coefficients in front of the independent variables show the degree of influence of each of them on the independent variable $(Y)$. For example, if a sign is preceded by a "+" coefficient, then it is said that there is a direct and linear dependence, if the sign is "-", then vice versa, the dependence is linear, but inverse.

In order to establish the influence of independent variables on the dependent one, we established the statistical base of the initial values of the model (Table 3 ).

\begin{tabular}{|c|c|c|c|c|}
\hline Country & $\begin{array}{c}\text { Number of } \\
\text { employees, ths. }\end{array}$ & $\begin{array}{l}\text { Initial investment } \\
\text { volume, thousand } \\
\text { dollars }\end{array}$ & $\begin{array}{c}\text { Cost of mergers and } \\
\text { acquisitions, thousand } \\
\text { dollars }\end{array}$ & $\begin{array}{l}\text { Average salary, } \\
\text { thousand dollars }\end{array}$ \\
\hline Austria & 208 & 4259000 & 1749000 & 2,176 \\
\hline China & 7903 & 110356000 & 5886000 & 0,92 \\
\hline Czech Republic & 694,7 & 2050000 & 1437000 & 1,05 \\
\hline Finland & 226 & 4359000 & 1383000 & 2,654 \\
\hline France & 1927 & 41254000 & 24202000 & 2,276 \\
\hline Germany & 2121 & 50266000 & 6357000 & 2,634 \\
\hline Hungary & 153,4 & 140000 & 4900 & 0,637 \\
\hline Indonesia & 148 & 202000 & 901000 & 0,372 \\
\hline Ireland & 109 & 6607000 & 10778000 & 2,549 \\
\hline Italy & 98 & 19686000 & 8716000 & 1,629 \\
\hline Japan & 482 & 48449000 & 20088000 & 2,481 \\
\hline Luxembourg & 82,1 & 7150000 & 2420000 & 5,021 \\
\hline Macao & 69,3 & 185000 & 101000 & 0,465 \\
\hline Norway & 78,1 & 2804000 & 1858000 & 3,305 \\
\hline Portugal & 145 & 1560000 & 2079000 & 0,952 \\
\hline Singapore & 161,8 & 26025000 & 4450000 & 3,106 \\
\hline Slovenia & 65,8 & 60000 & 202000 & 1,226 \\
\hline Sri Lanka & 444,7 & 276000 & 72200 & 0,266 \\
\hline Sweden & 572,7 & 8483000 & 9406000 & 2,465 \\
\hline Switzerland & 341 & 15828000 & 7922000 & 4,945 \\
\hline
\end{tabular}

Table 3. Output data of the econometric model

Source: UNCTAD Annual Report 2018; World Investment Report 2017;

World Investment Report 2018; calculation authors

According to the above analysis, it was found that there is a tight correlation $(\geq 0.66)$ between the number of employees and FDI for most of the countries studied, on the other hand, we assume that the initial investment has a greater impact on the creation of new work places than mergers and acquisitions. Based on the fact that the amount of FDI is actually equal to the sum of the initial investment and M\&A there is a high probability that the degree of interrelation between independent variables will be greater than their effect on the independent variable (multicolinearity), and the values of the parameters will be ineffective. In order to eliminate these phenomena, we used a modified least squares method. The specificity of this method is the calculation of the unbiased estimate for the variance of residuals $\left(\delta^{2}\right)$ obtained as follows: 


$$
\delta_{u}^{2}=\frac{1}{n-m} u^{\prime} S^{-1} u
$$

where:

$n$ - number of study options;

$m$ - number of degrees of freedom;

$u$ and $u^{\prime}-$ real and estimated distribution of residuals;

$S^{-1}$ - matrix inverse to the matrix of linearized initial values.

Linearization of the initial values of the model is an important step in the construction of linear regression, which contains the value of different orders. Among the data (Table 3) has the value of the 3rd (thousands), 6th (millions) and 9th (billions) order, in this context there is a need for their linearization, that is, reduction to proportionate values. In practice, such an operation is performed using the logarithm of the corresponding values by the decimal logarithm (Table 4).

Table 4. Output data values listed by the base of the decimal logarithm $(\lg (x))$

\begin{tabular}{|c|c|c|c|}
\hline $\begin{array}{c}\text { Number } \\
\text { of employees }\end{array}$ & Initial investment volume & $\begin{array}{l}\text { Cost of mergers } \\
\text { and acquisitions }\end{array}$ & Average salary \\
\hline 5,318063 & 6,629308 & 6,24279 & 0,337659 \\
\hline 6,897792 & 8,042796 & 6,76982 & $-0,03621$ \\
\hline 5,841797 & 6,311754 & 6,157457 & 0,021189 \\
\hline 5,354108 & 6,639387 & 6,140822 & 0,423901 \\
\hline 6,284882 & 7,615466 & 7,383851 & 0,357172 \\
\hline 6,326541 & 7,701274 & 6,803252 & 0,420616 \\
\hline 5,185825 & 5,146128 & 3,690196 & $-0,19586$ \\
\hline 5,170262 & 5,305351 & 5,954725 & $-0,42946$ \\
\hline 5,037426 & 6,820004 & 7,032538 & 0,40637 \\
\hline 4,991226 & 7,294157 & 6,940317 & 0,211921 \\
\hline 5,683047 & 7,685285 & 7,302937 & 0,394627 \\
\hline 4,914343 & 6,854306 & 6,383815 & 0,70079 \\
\hline 4,840733 & 5,267172 & 5,004321 & $-0,33255$ \\
\hline 4,892651 & 6,447778 & 6,269046 & 0,519171 \\
\hline 5,161368 & 6,193125 & 6,317854 & $-0,02136$ \\
\hline 5,208979 & 7,415391 & 6,64836 & 0,492201 \\
\hline 4,818226 & 4,778151 & 5,305351 & 0,08849 \\
\hline 5,648067 & 5,440909 & 4,858537 & $-0,57512$ \\
\hline 5,757927 & 6,928549 & 6,973405 & 0,391817 \\
\hline 5,532754 & 7,199426 & 6,898835 & 0,694166 \\
\hline
\end{tabular}

Source: UNCTAD Annual Report 2018; World Investment Report 2017;

World Investment Report 2018; calculation authors

Based on the data in table 4 a regression equation was built:

$$
Y=0,77+0,38 x_{1}+0,35 x_{2}-1,04 x_{3}
$$

where:

$Y$ - number of employees;

$x_{1}-$ volume of initial investments;

$x_{2}$ - cost of mergers and acquisitions;

$x_{3}$ - average salary in the country of origin of investments. 
The resulting equation establishes that the amount of initial investment and the cost of mergers and acquisitions have a positive effect on the number of employees, and the average salary in the country of origin of investments negatively affects the number of employees. In addition, it confirms our assumption that the initial investment creates more work places than the rising cost of mergers and acquisitions $-0.38 \%$ and $0.35 \%$, respectively. The difference is 0.0003 times, which in terms of the values of the 9 th order ( 1 billion) is $\$ 300$ thousand, which is obviously a rather tangible figure.

In order to verify the adequacy of the model, standard tests were used, first of all the value of the coefficient of determination $\mathrm{R}^{2}$, the value of which was 0.68 , which, given the number of observations (20), is an indicator of the model's high confidence, that is, the dispersion of the values of the increase in the number of people employed corresponds to the real indicators. The $P$-value for the coefficients was $0.019,0.028,0.018$, respectively, that is, all defined coefficients are significant and there is less than the established significance level of 0.05 .

We determined that the key factors that determine the mobility of labor resources within the framework of TNCs are FDI (primarily initial), as well as the level of remuneration (almost linearly inverse dependence). However, the weight share of other factors that are determined by the characteristic features of mobility within the framework of the modern knowledge economy and directly affect the international movement of employees within TNCs remains significant (about 34\%), and information and ICT technologies are crucial for the migration management of TNCs (Makedon, 2019). Also, an important role is played by the tendency to labor mobility and the presence of an active labor position, job satisfaction of the working TNC itself, the quality of the social environment of the TNCs, as well as the general situation on the labor market.

The UNCTAD statistics show that among countries with high correlation rates, a small amount of mergers and acquisitions is typical for such countries as China, Malaysia, France, Macao, Portugal. In Ireland, Italy, Japan, Norway and Slovenia for individual years (for the period from 1990 to 2017) the volume of M \& A transactions exceeds the volume of imported FDI several times. However, both the first and second group of countries demonstrate a steady growth in work places as FDI arrives ((UNCTAD Annual Report (2018). Therefore, in our opinion, it is impossible to talk about the existence of a unique connection between the method of attracting FDI and the dynamics of work places growth. Everything will depend on the production management style, the quantity and quality of new technologies introduced to the company as a result of mergers or acquisitions, as well as the future joint strategy for developing joint business.

\subsection{Relationship of national labor markets and global value chains}

Thus, an increasing number of employees are attracted to the global labor market precisely because of the intensification of the processes of transnationalisation of business, in fact, blurring the boundaries between individual states (Bradley, 2014). The question of the effects of FDI for both capital-importing countries and capital-exporting countries remains controversial. At the same time, the choice of the method of creating a business abroad as part of attracting FDI often depends on the technological effectiveness of production and the purposes of creating production abroad, rather than on formal beliefs in the benefits of using one or another mode of production development.

It should be also noted that participation in global value chains, as a rule, leads to the creation of new jobs in the domestic market from exports and more rapid employment growth, even if there is a large share of the import component in exports. In general, employment increases with trade, but the effect on employment from trade and participation in global value chains is quite diverse. Model VAC, as a rule, create new jobs. Wage costs as a component of domestic value added in export industries - an indicator of the potential for creating new jobs in export industries - grows with the rise of VAC positions (Fig. 2). 


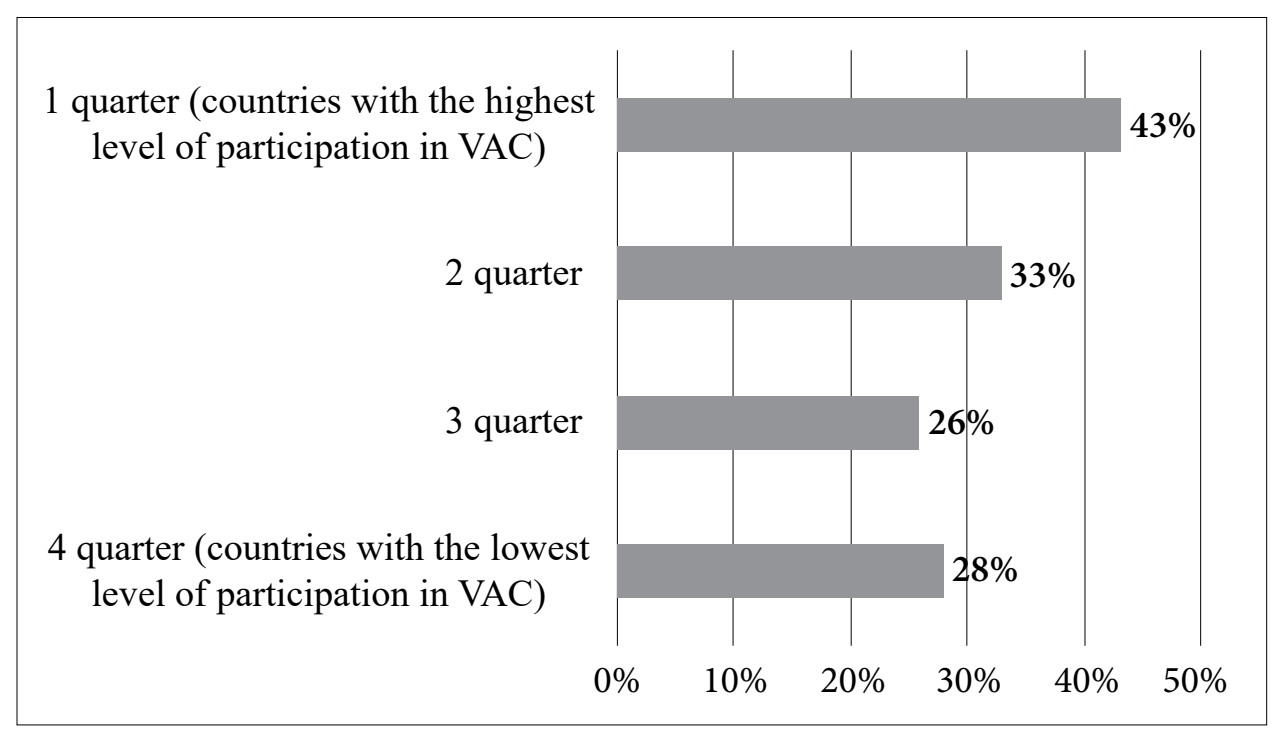

Fig. 2. VAC and labor component in the context of value added in 2017

Source: Information Economy Report 2017; calculation authors

The average labor force share is $43 \%$ for countries in the first quarter of the participation rate in VAC compared to a share of $28 \%$ for countries that are less involved in VAC. In addition, from 2007 to 2017 , countries that had a high level of growth in participation in VAC showed that their labor component in export industries grew faster (by 14\%) than in countries with a low level of growth in participation in VAC (9\%). This effect takes place regardless of participation in VAC combined with high external value added in exports. In other words, even if the participation of countries in VAC depends on a larger import component, which reduces the share of domestic value added, and the increase in the total share of employment in export industries will be higher than in cases where countries are less involved in the VAC (Wright, et. al., 2014).

Work places created using VAC vary in quality. Employees may face low wages, harsh working conditions, and insecurity because VAC jobs are more dependent on international demand and competition (Fig. 3).

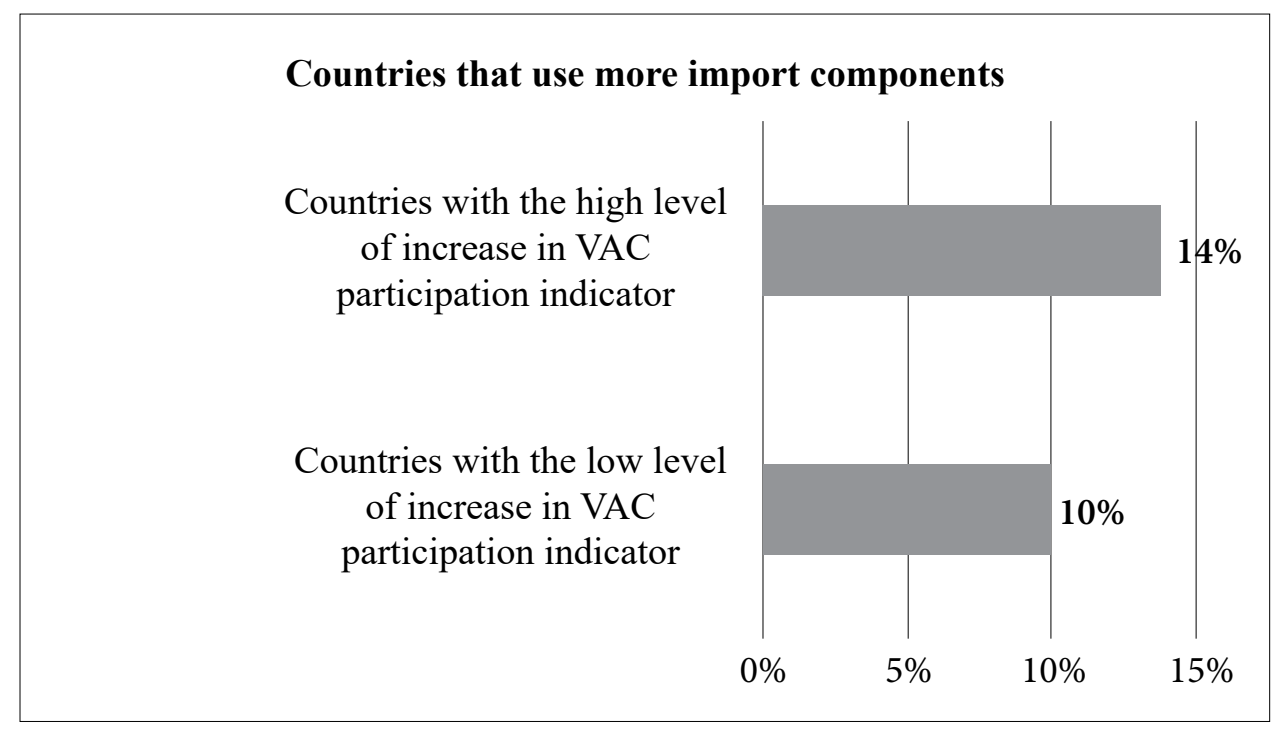




\section{Countries that use less import components}

Countries with the high level of increase in VAC participation indicator

Countries with the low level of increase in VAC participation indicator

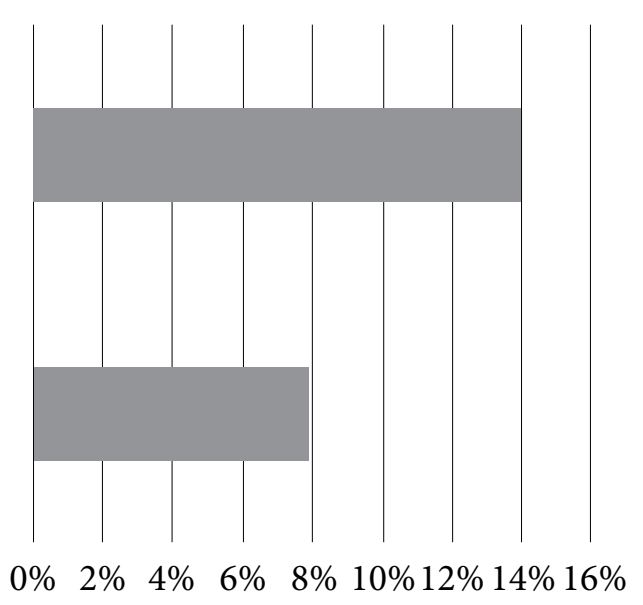

Fig. 3. Growth of the labor component of domestic value added in exports, in terms of the growth rate of VAC and the addition of external value

Source: Information Economy Report 2017;

World trade statistical review 2018; calculation authors

As a result of the growth of global production capabilities and the growth of export-oriented industries in many developing countries, coupled with increased global competition due to the entry of large new producers and exporters (located mainly in Asia), transnational corporations face significant pressure to reduce costs and increase productivity in their VAC (also referred to as "global production systems"). In turn, this puts considerable pressure on both wages and working conditions. Especially in labor-intensive industries (in the textile and clothing industry), where global buyers can use their preemption rights to cut costs, this effect often leads to lower wages, although there are significant differences between countries and between industries within such countries (Ryan, Pointon, 2017; Vakulyk, O.O., Andriichenko, N.S., Reznik, O.M., Volik, V.V., Yanishevska, K.D., 2019).

\section{Discussion}

Despite such initiatives, some types of employment in VAC provide unreliable incomes and employment prospects for employees. Participating countries face a range of potential risks associated with labor.

Expenditure burdens from global buyers mean that VAC-related employment can be unreliable and have poor working conditions. While some core employees receive more in terms of wages and privileges than key suppliers; global purchasing companies often reduce costs through the use of temporary workers or laborers in their enterprises and transfer certain types of work to subcontractors where working conditions are much worse. (Hummels, et. al., 2001).

Some VAC activities are independent, and displacement may lead to a decrease in local employment. Transnational corporations in the provision of services have more opportunities to move production between countries than most domestic firms. For simple tasks in the value chain and where the share of internal value added is low, the cost of moving is usually also lower. Similarly, global buyers using non-equity-related manufacturing mechanisms to source products from local suppliers (in domestic or foreign ownership) can redistribute an order from one country to another.

Export-oriented types of employment in general are more susceptible to fluctuations in global demand and supply, and therefore to the effects of factors that are far from the place of employment. VAC jobs may be lost in the event of fluctuations in demand and the onset of an economic crisis. Fluctuations in demand may be 
seasonal (as in the fashion industry), as a result of weather conditions (in the food industry), or caused by an economic downturn and crisis. Temporary workers are more at risk of losing their jobs, but this can also affect permanent employees.

\section{Conclusions}

The growth of employment in the framework of international corporations in modern conditions of transnationalisation and globalization of production processes occurs as a result of an increase in the number of FDI and international outsourcing of certain production tasks, which, due to transnationalisation, are two main forms of work places creation. Outsourcing in TNC divisions allows us to perform individual production tasks more quickly and professionally, with an overall cost savings for TNC. At the same time, TNK receives a stable, reliable, high-quality and professionally rendered service from an employee in outsourcing, while for an outsourcer, the key advantages are high salaries and no need to change their permanent place of residence. Foreign investments have a particularly significant impact on the quality of migration movements within TNCs, in particular, increasing labor productivity, security level of labor markets, and improving organizational methods of work against the background of the emergence of new jobs in regions of growing labor supply.

Having analyzed the activities of TNCs, our study showed a close correlation between the volume of FDI and the number of jobs created in the branches of TNC. We identified 4 groups of countries: 1) with the highest positive correlation values ( $44 \%$ of the total), 2) group of countries with low positive correlation $(30 \%), 3)$ countries with low negative correlation values $(13.5 \%), 4)$ countries with high negative correlation values $(12.5 \%)$. The effects of investments on the labor market largely depend on macroeconomic factors in the individual receiving country, as well as corporate strategy and organizational structure of TNCs.

\section{References}

Ahmed, A., Ejaz, A., Ali, R., Ishfaq Ahmad, I. (2018). Sectoral integration and investment diversification opportunities: evidence from Colombo Stock Exchange. Entrepreneurship and Sustainability Issues, 5(3), 514-527. https://doi.org/10.9770/jesi.2018.5.3(8)

Antras, P., Chor, D., Fally, T., Hillbery, R. (2012). Measuring the Upstreamness of Production and Trade Flows. American Economic Review, 102(3), 412-416.

Barlett, C.A., Ghoshal, S. (2016). Managing Across Borders: The Transnational Solution. Boston. MA: Harvard Business School Press

Bradley, H. (2014). Gender and Power in the Workplace: Analyzing the Impact of Economic Change. Basingstoke: Macmillan

Ciobanu, A.; Androniceanu, A.; Lazaroiu, G. (2019). An Integrated Psycho-Sociological Perspective on Public Employees' Motivation and Performance, Frontiers in Psychology 10:36. http://doi.org/10.3389/fpsyg.2019.00036

Dietzinbacher, E., Romero, I. (2007). Production Chains in an Interregional Framework: Identification by Means of Average Propagations Lenghts. International Regional Science Review, 30: 362-83

Fernandez-Stark, K., Frederick, S., Gereffi, G. (2011). The apparel global value chain: economic upgrading and workforce development. Center on Globalization, Governance \& Competitiveness, Duke University, November

Garbowski, M., Drobyazko, S., Matveeva, V., Kyiashko, O., \& Dmytrovska, V. (2019). Financial accounting of E-business enterprises. Academy of Accounting and Financial Studies Journal, 23(2).

Gereffi, G., Fernandez-Stark, K. (2011). Global Value Chain Analysis: A Primer. Duke University. North Carolina. USA

Guest, D. (2014). Industrial Relations and Human Resource Management//J. Storey (ed) HRM: A Critical Text. London: Thomson Learning

Dobrovolskienè, N., Tvaronavičienè, M., Tamošiūnienè, R. (2017). Tackling projects on sustainability: a Lithuanian case study. Entrepreneurship and Sustainability Issues, 4(4), 477-488. http://doi.org/10.9770/jesi.2017.4.4(6)

Drobyazko, S., Potyshniak, O., Radionova, N., Paranytsia, S., Nehoda, Y. (2019). Security of organizational changes via operational integration: ensuring methodology. Journal of Security and Sustainability Issues, 9(1), 1595-1612. http://doi.org/10.9770/jssi.2019.9.1(8) 
Harter, J., Schmidt, F., Hayes, T. (2012). Business-until-level relationship between employee satisfaction, employee engagement and business outcomes: a meta-analysis. Journal of Applied Psychology, 87(2), 268-79.

Hummels, D., Ishi, J., Yi, K.M. (2001). The nature and growth o0f vertical specialization in world trade. Journal of International Economics, 54(1), 75-96.

Huselid, M. (2015). The impact of human resource management practices on turnover, productivity and corporate financial performance. Academy of Management Journal, 38, 635-72.

Information Economy Report (2017). Digitalization, Trade and Development. Available on the Internet: https://unctad.org/es/PublicationsLibrary/ier2017_es.pdf

Korauš, A., Dobrovič, J., Polák, J., Backa, S. (2019). Security aspects: protection of people in connection with the use of personal identification numbers. Journal of Security and Sustainability Issues, 8(3), 319-330. http://doi.org/10.9770/jssi.2019.8.3(3)

Kostova, T., Roth, K. (2013). Social capital in multinational corporations and a micro-macro model of its formation. Academy of Management Review, 28 (2), 297-317.

Lialina, A. (2019). Labor market security in the light of external labor migration: new theoretical findings. Entrepreneurship and Sustainability Issues, 6(3), 1105-1125. http://doi.org/10.9770/jesi.2019.6.3(11)

Makedon V., Hetman O., Yemchuk L., Paranytsia N., Petrovska S. (2019). Human resource management for secure and sustainable development. Journal of Security and Sustainability Issues, 8(3), 345-354. http://doi.org/10.9770/jssi.2019.8.3(5)

Mathis, R. L. (2011). Human resource management. New York: South-Western Cengage Learning Publishing

Nikitina, M.G., Pobirchenko, V.V., Shutaieva, E.A.. Karlova, A.I. (2018). The investment component in a nation's economic security: the case of the Russian Federation. Entrepreneurship and Sustainability Issues, 6(2), 958-967. http://doi.org/10.9770/jesi.2018.6.2(32)

Pauly, L., Reich, S. (2016). National Structures and multinational corporate behavior: enduring differences in the age of globalization. International Organization, 51(1), 1-30.

Pickard, J. (2016). Lifelong earning: grey areas. People Management, July 29: 30-37.

Reznik, O.M., Shendryk, V., Zapototska, O., Popovich, E., Pochtovyi, M. (2019). The features of e-declaration as an effective tool to prevent corruption. Journal of Legal, Ethical and Regulatory Issues, 22 (Special Issue 2). URL: https://www.abacademies.org/abstract/ the-features-of-edeclaration-as-an-effective-tool-to-prevent-corruption-8187.html

Roberts, G. (2017). Recruitment and Selection: A Competency Approach. London: CIPD

Ryan A. J., Pointon J. (2017). Reward and performance management / J. Beardwell, T. Claydon. Human Resource Management: A Contemporary Approach, 5th edn. Harlow FT/Prentice Hall: 487-524.

Smethurst, S. (2016). State of mind, People Management, January 12, 24-29.

Shuyan, L., Fabuš, M. (2019). Study on the spatial distribution of China's Outward Foreign Direct Investment in EU and its influencing factors. Entrepreneurship and Sustainability Issues, 6(3),1080-1096. http://doi.org/10.9770/jesi.2019.6.3(16)

Shvetsova, O.A., Rodionova, E.A., Epstein, M. Z. (2018). Evaluation of investment projects under uncertainty: multi-criteria approach using interval data, Entrepreneurship and Sustainability Issues, 5(4), 914-928. http://doi.org/10.9770/jesi.2018.5.4(15)

Truss, C., Soane, E., Edwards, C. (2016). Working Life: Employee Attitudes and Engagement, Research Report. London: CIPD

Torrington, D., Hall, L., Taylor, S. (2012). Human Resource Management, 5th edn. Harlow: Prentice Hall

Tvaronavičienė, M. (2019). Insights into global trends of capital flows' peculiarities: emerging leadership of China. Administratie si Management Public, (32), 6-17, http://doi.org/10.24818/amp/2019.32-01

Vakulyk, O.O., Andriichenko, N.S., Reznik, O.M., Volik, V.V., Yanishevska, K.D. (2019). International aspect of a legal regulation in the field of financial crime counteraction by the example of special services of Ukraine and the CIS countries. Journal of Legal, Ethical and Regulatory Issues, 22 (1). URL: https://www.abacademies.org/articles/international-aspect-of-a-legal-regulation-in-the-field-offinancial-crime-counteraction-by-the-example-of-special-services-of-ukr-7870.html

Zeibote, Z., Volkova, T., Todorov, K. (2019). The impact of globalization on regional development and competitiveness: cases of selected regions. Insights into Regional Development, 1(1), 33-47. https://doi.org/10.9770/ird.2019.1.1(3) 
World Investment Report (2017). Overview. Available on the Internet: https://unctad.org/en/PublicationsLibrary/wir2017_overview_ ru.pdf

World Investment Report (2018). Overview. Available on the Internet: https://unctad.org/en/PublicationsLibrary/wir2018_overview_ ru.pdf

World trade statistical review (2018). World Trade Organization. Available on the Internet: https://www.wto.org/english/res_e/statis_e/ wts2018_e/wts2018_e.pdf

Wright, P., McMahan, G., McWilliams, A. (2014). Human resources and sustained comparative advantage: a resource-based perspective. International Journal of Human Resource Management, 5(2), 301-326.

UNCTAD Annual Report (2018). Available on the Internet: https://unctad.org/en/PublicationsLibrary/dom2019_en.pdf

UNDP. Human Development Report (2018). Available on the Internet: http://hdr.undp.org/en/2018-update

Svetlana DROBYAZKO, Ph.D in Economics, Professor, European academy of sciences, Coventry, United Kingdom ORCID ID: orcid.org/0000-0003-2022-0126

Iryna ALIEKSIEIENKO, Professor, Dnipropetrovsk State University of Internal Affairs

ORCID ID: orcid.org/0000-0003-2539-4412

Maryna KOBETS, Ph.D., State Research Institute of the Ministry of Internal Affairs of Ukraine

ORCID ID: orcid.org/0000-0001-1748-2935

Elena KISELYOVA, Doctor of Law, Associate Professor, Sumy State University

ORCID ID: orcid.org/0000-0001-4857-5575

Mykola LOHVYNENKO, Candidate of Legal Sciences, Sumy State University

ORCID ID: orcid.org/0000-0001-9734-1340

This work is licensed under the Creative Commons Attribution International License (CC BY).

http://creativecommons.org/licenses/by/4.0/ 